\title{
The Determination of Parkinson's Drugs in Human Urine by Applying Chemometric Methods
}

\author{
Guzide Pekcan Ertokus \\ Department of Chemistry, Faculty of Science \& Art, Süleyman Demirel University, 32260 Isparta, Turkey \\ Correspondence should be addressed to Guzide Pekcan Ertokus; guzideertokus@sdu.edu.tr
}

Received 9 April 2019; Revised 10 June 2019; Accepted 20 June 2019; Published 9 July 2019

Academic Editor: Charles L. Wilkins

Copyright ( 2019 Guzide Pekcan Ertokus. This is an open access article distributed under the Creative Commons Attribution License, which permits unrestricted use, distribution, and reproduction in any medium, provided the original work is properly cited.

\begin{abstract}
The spectrophotometric-chemometric analysis of levodopa and carbidopa that are used for Parkinson's disease was analyzed without any prior reservation. Parkinson's drugs in the urine sample of a healthy person (never used drugs in his life) were analyzed at the same time spectrophotometrically. The chemometric methods used were partial least squares regression (PLS) and principal component regression (PCR). PLS and PCR were successfully applied as chemometric determination of levodopa and carbidopa in human urine samples. A concentration set including binary mixtures of levodopa and carbidopa in 15 different combinations was randomly prepared in acetate buffer ( $\mathrm{pH}$ 3.5).). UV spectrophotometry is a relatively inexpensive, reliable, and less time-consuming method. Minitab program was used for absorbance and concentration values. The normalization values for each active substance were good (r2>0.9997). Additionally, experimental data were validated statistically. The results of the analyses of the results revealed high recoveries and low standard deviations. Hence, the results encouraged us to apply the method to drug analysis. The proposed methods are highly sensitive and precise, and therefore they were implemented for the determination of the active substances in the urine sample of a healthy person in triumph.
\end{abstract}

\section{Introduction}

Levodopa, which has the [(-)-3-(3,4-dihydroxyphenyl)-Lalanine] chemical expansion, is an antiparkinson drug and a dopamine precursor. It is often used in combination with carbidopa and acts as an amino acid decarboxylase inhibitor [1]. To treat Parkinson's disease, levodopa is returned to dopamine in the brain and readily crosses the blood barrier [2]. [(-)-L-2-(3,4-dihydroxy benzyl)-2-hydrazino propionic acid] is the chemical structure of carbidopa, another drug used in the treatment of this disease [3]. Carbidopa is a catechol related compound [4]. The chemical formulas of these compounds are indicated in Figure 1 [5].

When levodopa is combined with carbidopa, the side effects are normally reduced, and the concentration of dopamine is efficacious when these are given at an appropriate level [4].

Multivariate calibration methods (PLS-PCR) were developed using various mathematical operations to determine two or more compounds in the same sample without any chemical separation $[6,7]$. The chemometric methods are utilized in the spectral data analysis in overlapping spectra containing two or more compounds [8]. Minitab 17 program, which is statistical analysis software (Anova, Ankara, Turkey), to determine concentration, allows quantitative analysis to evaluate absorbance data simultaneously [9]. Chemometric calibration methods are considered the best techniques to determine the amount of each component in complex mixtures. The most commonly accepted chemometric methods in drug analysis are principal component regression (PCR) and partial least squares regression (PLS) [10]. A relationship between matrices of chemical data can be determined using chemometric methods [11].

A concentration data matrix (y-block) and absorbance data matrix (x-block) were used to generate PLS and PCR calibration equations at the calibration stage. The first step in the chemometric calculations was a PCA, which allowed the calculation of the amount of available data given the original variables. Using the first few of the prediction variables instead of the components of the prediction variables reduced 
<smiles>N[C@@H](Cc1ccc(O)c(O)c1)C(=O)O</smiles><smiles>C[C@](Cc1ccc(O)c(O)c1)(NN)C(=O)O</smiles>

FIgURE 1: The chemical formulas of Parkinson's drugs.

the number of new components (PC) created. The PLS and PCR were applied, providing precision, accuracy, and selectivity in the results.

Different analytical methods have been used in the literature to identify levodopa and carbidopa both separately and together. Moreover, there are several methods for diagnosing Parkinson's disease including spectrophotometric methods [1-14], electrochemical methods [15-22], chromatographic methods [23-52], ATR-FTIR spectrometric method [53], NMR [54], and capillary electrophoresis [55, 56].

In this study, we report analysis of levodopa and carbidopa in urine sample of a healthy person with chemometric methods. Levodopa and carbidopa are contained in the same drug used for treatment of Parkinson's disease. Our aim with this drug was to carry out quantitative analyses using chemometry in urine sample. Levodopa and carbidopa provide the same wavelength and overlapping spectra. Although it is difficult to analyze this situation by classical methods without any preseparation process, the chemometric methods and their determinations were successfully performed next to each other.

The validity of this method is clearly examined in terms of accuracy, precision, and selectivity. The chemometric methods used in the study were successfully carried out without any preseparation method for simultaneous determination of levodopa and carbidopa in urine sample of a healthy person. The results were statistically compared to each other and the validity of the methods according to the calculated analytical parameters (SD, RDS, PRESS, etc.) was evaluated.

\section{Experimental}

2.1. Materials. Stock solutions of $25 \mathrm{mg} / 250 \mathrm{~mL}$ levodopa (Sigma) and carbidopa (Sigma) in the analytical purity used in this study were prepared in acetate buffer ( $\mathrm{pH} 3.5)$. Measurement of the synthetic mixture (for verification and calibration) in the concentration set prepared symmetrically from the active ingredients of the drugs was recorded with the UV-VIS-1700 PharmaSpec Spectrophotometer (Shimadzu, Kyoto, Japan).

\subsection{Experimental Design and Sample Preparation. Absorp-} tion spectra of levodopa and carbidopa were recorded at 0.1 ranges from $210 \mathrm{~nm}$ to $310 \mathrm{~nm}$. The calibration matrix, training, and validation kits (Table 1 and Figure 2) contain a two-component mixture of different proportions. In the analysis of prepared synthetic mixtures and human urine samples, the data were calculated using PLS and PCR. $4.0 \mathrm{mg}$ $\mathrm{L}^{-1}$ and $25.0 \mathrm{mg} \mathrm{L}^{-1}$ of levodopa and carbidopa, respectively,

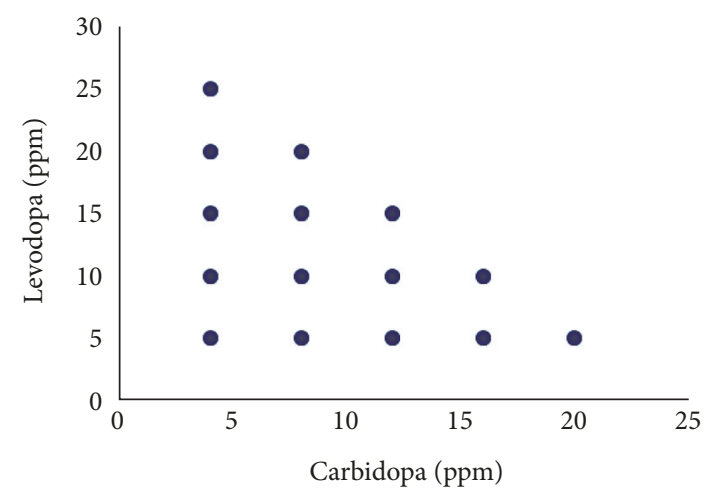

FIGURE 2: Design for concentration set.

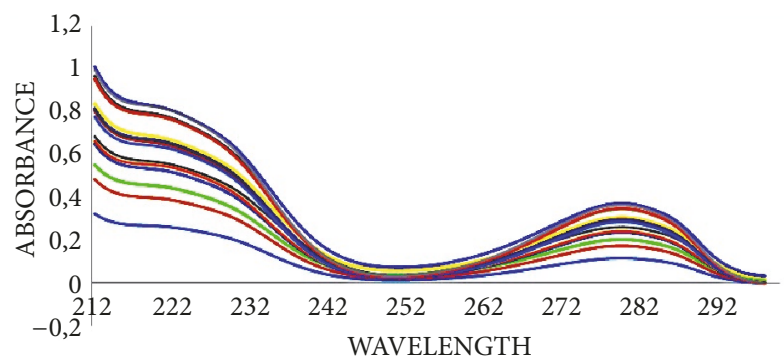

FIgURE 3: Absorption spectra of levodopa-carbidopa mixtures.

were placed in flasks $(25 \mathrm{~mL})$ and dissolved by adding acetate buffer to develop the experimental design. The partial factorial design was used in preparing the calibration set. Chemometric methods are based on suitable experimental design.

2.3. Procedure to Analyze Levodopa and Carbidopa in Urine Sample of a Healthy Person. Twenty-four-hour drug-free human urine samples were collected from healthy individuals and stored at $-20^{\circ} \mathrm{C}$ before analysis. The urine samples were collected over a 4 -h period in plastic containers before analysis. A healthy human urine sample was diluted with 20 -fold deionized water to remove the matrix. Potentially interfering compounds need to be removed before analysis. Protein precipitation of urine samples was carried out by the addition of acetonitrile. After thawing to ambient temperature, $1 \mathrm{~mL}$ of urine was mixed with $9 \mathrm{~mL}$ of acetonitrile in order to precipitate proteins from the specimen, vortexed for $3 \mathrm{~min}$. The resulting different (4-20 $\left.\mathrm{mg} \mathrm{L}^{-1}\right)$ concentrations of levodopa and carbidopa were added to the analysis. In biological samples, matrix effects were taken into consideration and uv-visible measurements were taken. In the calculations of biological samples, the dilution process in the experimental stage was taken into consideration.

\section{Results and Discussions}

3.1. Absorption Spectra of Levodopa-Carbidopa Mixtures. Absorption spectra of levodopa-carbidopa mixtures were in the range of $210 \mathrm{~nm}-310 \mathrm{~nm}$ (Figure 3).

When the absorbance-concentration plots for levodopa and carbidopa are examined, it is seen that the absorbance 
TABLE 1: Concentration set for levodopa and carbidopa.

\begin{tabular}{lcc}
\hline No. & & Concentration, mg L \\
& Levodopa & \\
Carbidopa \\
\hline 1 & 4 & 5 \\
2 & 4 & 10 \\
3 & 4 & 15 \\
4 & 4 & 20 \\
5 & 4 & 25 \\
6 & 8 & 5 \\
7 & 8 & 10 \\
8 & 8 & 15 \\
9 & 8 & 20 \\
10 & 12 & 5 \\
11 & 12 & 10 \\
12 & 12 & 15 \\
13 & 16 & 5 \\
14 & 16 & 10 \\
15 & 20 & 5 \\
\hline
\end{tabular}

TABLE 2: Calculated statistical parameters by chemometric methods [57].

\begin{tabular}{|c|c|c|c|c|}
\hline \multirow[b]{2}{*}{ Mix } & \multicolumn{2}{|c|}{ Levodopa } & \multicolumn{2}{|c|}{ Carbidopa } \\
\hline & Recovery \% & Recovery \% & Recovery \% & Recovery \% \\
\hline No & PLS & PCR & PLS & PCR \\
\hline 1 & 99.86 & 99.75 & 99.8 & 100 \\
\hline 2 & 99.50 & 99.25 & 99.7 & 99.6 \\
\hline 3 & 97.25 & 99.50 & 99.73 & 99.27 \\
\hline 4 & 99.25 & 100.00 & 99.85 & 99.7 \\
\hline 5 & 98.75 & 97.25 & 99.8 & 99.84 \\
\hline 6 & 98.00 & 99.75 & 99 & 99.8 \\
\hline 7 & 99.38 & 99.63 & 99.6 & 99.5 \\
\hline 8 & 99.38 & 99.38 & 99.67 & 99.8 \\
\hline 9 & 98.63 & 99.50 & 99.75 & 99.9 \\
\hline 10 & 99.50 & 99.58 & 99.8 & 98.4 \\
\hline 11 & 99.67 & 99.00 & 98.9 & 99.4 \\
\hline 12 & 99.33 & 99.67 & 99.93 & 99.73 \\
\hline 13 & 99.75 & 99.88 & 99.2 & 99.8 \\
\hline 14 & 99.69 & 99.75 & 99.8 & 99.8 \\
\hline \multirow[t]{3}{*}{15} & 99.88 & 99.80 & 99.6 & 99.4 \\
\hline & Mean $=99.18$ & Mean=99.18 & Mean=99.61 & Mean $=99.61$ \\
\hline & $R S D \%=0.74$ & $R S D \%=0.74$ & $R S D \%=0.32$ & $R S D \%=0.32$ \\
\hline
\end{tabular}

value increases as the concentration increases. The linear relationship [58] between absorbance and concentration was confirmed by the fact that the regression coefficient [59] is close to the individual values (Table 3).

3.2. Chemometric Methods (PLS and PCR). Recovery (\%), mean, and recovery value (\%) (Table 2) were calculated from added and found values for levodopa-carbidopa mixtures.

3.3. Validation of the Method. The chemometric methods were validated on the basis of ICH rules [60-62] for linearity, accuracy, intraday and interday sensitivity, detection limit, and quantitative limit.
In order to verify the validity of the system, one of the calculated parameters is the PRESS (equation (1)) [63] (Table 3) value known as the predictive residual error. The difference between the actual and the estimated value is calculated from the sum of the squares. If the PRESS value is close to zero, it indicates that the method used is good. It is particularly useful in comparing the prediction power of different methods.

$$
\text { PRESS }=\sum_{i=1}^{n}\left(C_{i}^{\text {added }}-C_{i}^{\text {found }}\right)^{2}
$$


TABLE 3: Validation parameters for chemometric determination of levodopa and carbidopa using PLS and PCR methods.

\begin{tabular}{|c|c|c|c|}
\hline Parameters & Method & Levodopa & Carbidopa \\
\hline$\lambda_{\max }(\mathrm{nm})$ & & $280 \mathrm{~nm}$ & $280 \mathrm{~nm}$ \\
\hline Correlation Coefficient $\left(\mathrm{R}^{2}\right)$ & & 0.9997 & 0.9992 \\
\hline \multirow{2}{*}{ PRESS } & PLS & 0.004 & 0.002 \\
\hline & PCR & 0.0001 & 0.002 \\
\hline \multirow{2}{*}{ RMSEC } & PLS & $4.21 \times 10^{-3}$ & $9.42 \times 10^{-3}$ \\
\hline & PCR & $6.6 \times 10^{-4}$ & $9.42 \times 10^{-3}$ \\
\hline \multirow{2}{*}{$\mathrm{LOD}(\mu \mathrm{g} / \mathrm{mL})$} & PLS & 0.052043 & 0.04631 \\
\hline & PCR & 0.04631 & 0.140332 \\
\hline \multirow{2}{*}{ LOQ $(\mu \mathrm{g} / \mathrm{mL})$} & PLS & 0.157706 & 0.052817 \\
\hline & PCR & 0.140332 & 0.160051 \\
\hline \multirow{2}{*}{ Accuracy (\% Recovery \pm SD) } & PLS & $99.18 \pm 0.74$ & $99.61 \pm 0.32$ \\
\hline & PCR & $99.18 \pm 0.74$ & $99.61 \pm 0.32$ \\
\hline \multicolumn{4}{|l|}{ Precision (Reproducibility) } \\
\hline \multirow{2}{*}{$\begin{array}{l}\text { Intraday }(\% \text { Recovery } \pm \text { SD) } \\
(n: 6)\end{array}$} & PLS & $99.65 \pm 0.95$ & $99.97 \pm 0.64$ \\
\hline & PCR & $99.96 \pm 0.75$ & $99.98 \pm 0.42$ \\
\hline \multirow{2}{*}{$\begin{array}{l}\text { Interday (\% Recovery } \pm \text { SD) } \\
(\mathrm{n}: 6)\end{array}$} & PLS & $99.75 \pm 0.30$ & $98.95 \pm 0.82$ \\
\hline & PCR & $98.98 \pm 0.41$ & $99.89 \pm 0.81$ \\
\hline
\end{tabular}

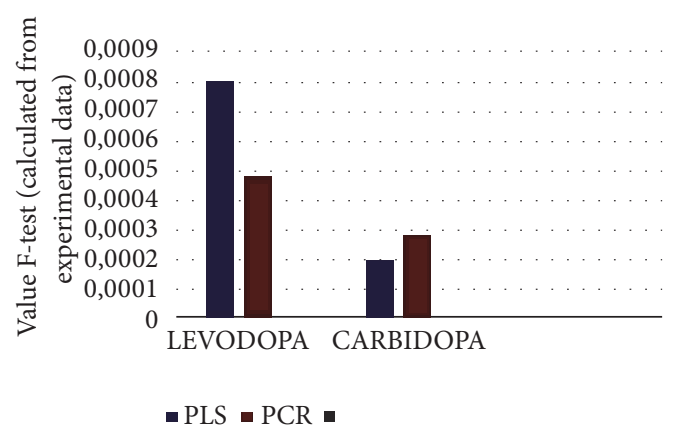

FIGURE 4: The results of the one-way ANOVA test according to Snedecor's F-test.

$C_{i}^{\text {added }}$ is actual concentration, the added concentration of drug; $C_{i}^{\text {found }}$ is predicted concentration, the calculated concentration of drug. [64].

Another validation parameter is RMSEC (equation (2))

$$
\text { RMSEC }=\sqrt{\frac{P R E S S}{n}}
$$

The observable limit (LOD) and the detection limit (LOQ) parameters are interrelated but have different definitions (equations (3) and (4)) [65].

$$
\begin{aligned}
& L O D=\frac{3 S a}{m} \\
& L O Q=\frac{10 S a}{m}
\end{aligned}
$$

$m$ is slope; LOQ $>$ LOD and LOQ $=$ LOD were taken into consideration while evaluating the calculated LOD values [66].
The limit of detection (LOD) is defined as the lowest concentration of an analyte in a sample that can be detected. The limit of quantification (LOQ) is defined as the lowest concentration of an analyte in a sample that can be determined with acceptable precision and accuracy under the stated operational conditions of the method (Table 3 ).

The values obtained from the two chemometric methods (PLS and PCR) used in this study were compared with the variance analysis-Snedecor's F-test [67]. Analysis of variance (ANOVA) is a powerful statistical technique used to test hypotheses about whether the difference between averages of two or more groups is significant. For PLS method, the F-test value for levodopa was 0.00080 and the p-value was 0.98 for the intergroup degrees of freedom $=1$, and intragroup degrees of freedom $=28 \%$. For the carbidopa, the F-test value was calculated as 0.00020 and the p-value was 0.99 for the intergroup degrees of freedom $=1$, and intragroup degrees of freedom $=28 \%$. In the PCR method, the F-test value for levodopa was calculated to be 0.00048 and p-value was 0.98 for the intergroup degrees of freedom $=1$, and intragroup degrees of freedom $=28 \%$. For the carbidopa, the F-test value was calculated as 0.00029 and the p-value was 0.99 for the intergroup degrees of freedom $=1$, and intragroup degrees of freedom $=28 \%$ and $95 \%$ confidence interval (Figure 4 ).

3.4. Analysis of Human Urine Samples. The experimental results of the two methods for human urine samples are given in Table 4 . One can see that the obtained results are very close to each other. The suggested methods were successfully applied for the determination of the drugs used in healthy human urine samples and yielded convincing results as shown in Table 4.

All statistical parameters and numeric values appear suitable for simultaneous identification of these drugs in human urine samples. 
TABLE 4: Determination of levodopa and carbidopa in human urine using PLS and PCR methods.

\begin{tabular}{|c|c|c|c|c|c|c|}
\hline \multirow[b]{2}{*}{$\begin{array}{l}\text { Mix } \\
\text { No }\end{array}$} & \multicolumn{3}{|c|}{ Levodopa (PLS) } & \multicolumn{3}{|c|}{ Carbidopa (PLS) } \\
\hline & $\begin{array}{c}\text { Added } \\
\left(\mathrm{mg} \mathrm{L}^{-1}\right)\end{array}$ & $\begin{array}{c}\text { Found } \\
\left(\mathrm{mg} \mathrm{L}^{-1}\right)\end{array}$ & $\begin{array}{l}\text { Recovery } \\
(\% \text { mean })\end{array}$ & $\begin{array}{c}\text { Added } \\
\left(\mathrm{mg} \mathrm{L}^{-1}\right)\end{array}$ & $\begin{array}{c}\text { Found } \\
\left(\mathrm{mg} \mathrm{L}^{-1}\right)\end{array}$ & $\begin{array}{l}\text { Recovery } \\
\text { (\% mean) }\end{array}$ \\
\hline 1 & 4 & 3.98 & 99.50 & 4 & 3.97 & 99.25 \\
\hline 2 & 8 & 7.98 & 99.75 & 8 & 7.96 & 99.50 \\
\hline 3 & 12 & 11.96 & 99.67 & 12 & 11.97 & 99.75 \\
\hline 4 & 16 & 15.98 & 99.88 & 16 & 15.99 & 99.94 \\
\hline 5 & 20 & 19.89 & 99.45 & 20 & 19.98 & 99.90 \\
\hline Mean $\pm \mathrm{SD} *$ & & & 99.65 & & & 99.67 \\
\hline \multirow[t]{2}{*}{ Standard Deviation } & & & 0.177 & & & 0.29 \\
\hline & \multicolumn{3}{|c|}{ Levodopa (PCR) } & \multicolumn{3}{|c|}{ Carbidopa (PCR) } \\
\hline $\begin{array}{l}\text { Mix } \\
\text { No }\end{array}$ & $\begin{array}{c}\text { Added } \\
\left(\mathrm{mg} \mathrm{L}^{-1}\right)\end{array}$ & $\begin{array}{c}\text { Found } \\
\left(\mathrm{mg} \mathrm{L}^{-1}\right)\end{array}$ & $\begin{array}{l}\text { Recovery } \\
\text { (\% mean) }\end{array}$ & $\begin{array}{c}\text { Added } \\
\left(\mathrm{mg} \mathrm{L}^{-1}\right)\end{array}$ & $\begin{array}{c}\text { Found } \\
\left(\mathrm{mg} \mathrm{L}^{-1}\right)\end{array}$ & $\begin{array}{l}\text { Recovery } \\
\text { (\% mean) }\end{array}$ \\
\hline 1 & 4 & 3.96 & 99.00 & 4 & 3.98 & 99.5 \\
\hline 2 & 8 & 7.96 & 99.50 & 8 & 7.98 & 99.75 \\
\hline 3 & 12 & 11.97 & 99.75 & 12 & 11.99 & 99.92 \\
\hline 4 & 16 & 15.96 & 99.75 & 16 & 15.98 & 99.88 \\
\hline 5 & 20 & 19.98 & 99.90 & 20 & 19.97 & 99.85 \\
\hline Mean & & & 99.58 & & & 99.78 \\
\hline \multirow[t]{2}{*}{ Standard Deviation } & & & 0.35 & & & 0.17 \\
\hline & \multicolumn{3}{|c|}{ Levodopa (Classical UV-Vis) } & \multicolumn{3}{|c|}{ Carbidopa (Classical UV-Vis) } \\
\hline $\begin{array}{l}\text { Mix } \\
\text { No }\end{array}$ & $\begin{array}{c}\text { Added } \\
\left(\mathrm{mg} \mathrm{L}^{-1}\right)\end{array}$ & $\begin{array}{l}\text { Found } \\
\left(\mathrm{mg} \mathrm{L}^{-1}\right)\end{array}$ & $\begin{array}{l}\text { Recovery } \\
\text { (\% mean) }\end{array}$ & $\begin{array}{c}\text { Added } \\
\left(\mathrm{mg} \mathrm{L}^{-1}\right)\end{array}$ & $\begin{array}{l}\text { Found } \\
\left(\mathrm{mg} \mathrm{L}^{-1}\right)\end{array}$ & $\begin{array}{l}\text { Recovery } \\
\text { (\% mean) }\end{array}$ \\
\hline 1 & 4 & 3.97 & 99.25 & 4 & 3.95 & 98.75 \\
\hline 2 & 8 & 7.95 & 99.38 & 8 & 7.99 & 99.88 \\
\hline 3 & 12 & 11.95 & 99.58 & 12 & 11.96 & 99.67 \\
\hline 4 & 16 & 15.93 & 99.56 & 16 & 15.98 & 99.88 \\
\hline 5 & 20 & 19.99 & 99.95 & 20 & 19.96 & 99.80 \\
\hline Mean & & & 99.54 & & & 99.60 \\
\hline Standard Deviation & & & 0.26 & & & 0.48 \\
\hline
\end{tabular}

\section{Conclusion}

With the UV-VIS spectrophotometric method, the drug active ingredients in the healthy human urine sample were determined as fast and reliable. The results obtained from urine samples were compared with the results obtained by conventional UV-VIS spectrophotometry. In this study, the results were obtained with support from chemometric methods and the results were still more reliable. At the same time, due to the fact that each drug substance was determined simultaneously with chemometric methods, time and cost losses were prevented.

After certain processes, the proteins were precipitated from the urine, and measurements were taken in the UVVisible region. The data obtained were evaluated chemometrically. The main advantage of the method is the ability to analyze simultaneously the two compounds under similar conditions. The achieved method validation results show the reliability of the method. The high recovery values also showed that the drugs did not bind to urine proteins. The results obtained suggest that this method could be used suitably for simultaneous determination of levodopa and carbidopa in urine.

\section{Data Availability}

The data used to support the findings of this study are included within the article.

\section{Conflicts of Interest}

The author declares that there are no conflicts of interest regarding the publication of this paper.

\section{References}

[1] E. Dinç, S. Kaya, T. Doganay, and D. Baleanu, "Continuous wavelet and derivative transforms for the simultaneous quantitative analysis and dissolution test of levodopa-benserazide tablets," Journal of Pharmaceutical and Biomedical Analysis, vol. 44, no. 4, pp. 991-995, 2007.

[2] P. Nagaraja, R. A. Vasantha, and K. R. Sunitha, "A sensitive and selective spectrophotometric estimation of catechol derivatives in pharmaceutical preparations," Talanta, vol. 55, no. 6, pp. 1039-1046, 2001.

[3] K. Kaur, A. K. Malik, B. Singh, and M. Godarzi, "Simultaneous spectrophotometric determination of carbidopa and levodopa 
by partial least squares regression, principal component regression and least squares support vector machine methods," Thai Journal of Pharmaceutical Sciences, vol. 33, no. 4, pp. 123-136, 2009.

[4] I. A. Sima, R. D. Naşcu-Briciu, and C. Sarbu, "Simultaneous determination of levodopa and carbidopa in pharmaceuticals by principal component regression," Revue Roumaine de Chimie, vol. 58, no. 7-8, pp. 705-710, 2013.

[5] C. Zapata-Urzúa, M. Pérez-Ortiz, M. Bravo, A. C. Olivieri, and A. Álvarez-Lueje, "Simultaneous voltammetric determination of levodopa, carbidopa and benserazide in pharmaceuticals using multivariate calibration," Talanta, vol. 82, no. 3, pp. 962$968,2010$.

[6] T. Madrakian and M. Mohammadnejad, "Simultaneous spectrophotometric determination of levodopa and carbidopa in pharmaceutical formulations and water samples by using mean centering of ratio spectra and $\mathrm{H}$-point standard addition methods," Chemical \& Pharmaceutical Bulletin, vol. 55, no. 6, pp. 865870, 2007.

[7] M. J. Culzoni, H. C. Goicoechea, G. A. Ibañez et al., "Secondorder advantage from kinetic-spectroscopic data matrices in the presence of extreme spectral overlapping: a multivariate curve resolution-Alternating least-squares approach," Analytica Chimica Acta, vol. 614, no. 1, pp. 46-57, 2008.

[8] S. Y. Li, Q. L. Guo, W. Yuan, Y. C. Hou, and L. M. Du, "Spectrophotometric study of the charge transfer complexation of some amino acid derivative drugs as electron donors with 7,7,8,8-tetracyanoquinodimethane," Bulletin of the Chemical Society of Ethiopia, vol. 24, no. 1, pp. 21-30, 2010.

[9] B. Uslu and S. A. Özkan, "Determination of binary mixtures of levodopa and benserazide in pharmaceuticals by ratio-spectra derivative spectrophotometry," Analytical Letters, vol. 35, no. 2, pp. 303-314, 2002.

[10] M. F. Abdel-Ghany, L. A. Hussein, M. F. Ayad, and M. M. Youssef, "Investigation of different spectrophotometric and chemometric methods for determination of entacapone, levodopa and carbidopa in ternary mixture," Spectrochimica Acta Part A: Molecular and Biomolecular Spectroscopy, vol. 171, pp. 236-245, 2017.

[11] T. Madrakian, A. Afkhami, M. Borazjani, and M. Bahram, "Simultaneous derivate spectrophotometric determination of levodopa and carbidopa in pharmaceutical preparations," Bulletin of the Korean Chemical Society, vol. 25, no. 12, pp. 17641768, 2004.

[12] M. Chamsaz, A. Safavi, and J. Fadaee, "Simultaneous kineticspectrophotometric determination of carbidopa, levodopa and methyldopa in the presence of citrate with the aid of multivariate calibration and artificial neural networks," Analytica Chimica Acta, vol. 603, no. 2, pp. 140-146, 2007.

[13] P. C. Damiani, A. C. Moschetti, A. J. Rovetto, F. Benavente, and A. C. Olivieri, "Design and optimization of a chemometricsassisted spectrophotometric methods for the simultaneous determination of levodopa and carbidopa in pharmaceutical products," Analytica Chimica Acta, vol. 543, no. 1-2, pp. 192-198, 2005.

[14] J. Coello, "Simultaneous kinetic-spectrophotometric determination of levodopa and benserazide by bi- and three-way partial least squares calibration," Talanta, vol. 53, no. 3, pp. 627-637.

[15] V. N. Palakollu, N. Thapliyal, T. E. Chiwunze, R. Karpoormath, S. Karunanidhi, and S. Cherukupalli, "Electrochemically reduced graphene oxide/Poly-Glycine composite modified electro for sensitive determination of L-dopa," Materials Science and
Engineering C: Materials for Biological Applications, vol. 77, pp. 394-404, 2017.

[16] A. Hatefi-Mehrjardi, M. A. Karimi, A. Barani, and M. Soleymanzadeh, "Poly-(dianix blue) modified glassy carboh electrode as an electrochemical sensor for simultaneous determination of levodopa, ascorbic and uric acids," Analytical and Bioanalytical Electrochemistry, vol. 9, no. 3, pp. 295-311, 2017.

[17] N. Rastakhiz, H. Beitollahi, A. Kariminik, and F. Karimi, "Voltammetric determination of carbidopa in the presence of uric acid and folic acid using a modified carbon nanotube paste electrode," Journal of Molecular Liquids, vol. 172, pp. 66-70, 2012.

[18] M. Shoghi-Kalkhoran, F. Faridbod, P. Norouzi, and M. R. Ganjali, "Praseodymium molybdate nanoplates/reduced graphene oxide nanocomposite based electrode for simultaneous electrochemical determination of entacapone, levodopa and carbidopa," Journal of Materials Science: Materials in Electronics, vol. 29, no. 1, pp. 20-31, 2018.

[19] M. Quintino, M. Yamashita, and L. Angnes, "Voltammetric studies and determination of levodopa and carbidopa in pharmaceutical products," Electroanalysis, vol. 18, no. 7, pp. 655-661, 2006.

[20] A. A. Rabinca, M. Buleandra, F. Tache et al., "Voltametric method for simultaneous determination of L-dopa and benserazide," Current Analytical Chemistry, vol. 13, no. 3, pp. 218-224, 2017.

[21] B. T. Demircigil, B. Dogan-Topal, and S. A. Ozkan, "Simultaneous determination of L-dopa and benserazide in binary mixtures using first derivative of the ratio-voltammetric methods based on their oxidation on solid electrode," Collection of Czechoslovak Chemical Communications, vol. 76, no. 12, pp. 1717-1736, 2011.

[22] E. K. Savan and G. Erdoğdu, "Simultaneous determination of levodopa and benserazide using poly(3-methylthiophene) and a multi-walled carbon nanotube sensor," Journal of Solid State Electrochemistry, vol. 21, no. 8, pp. 2209-2217, 2017.

[23] P. P. Raut and S. Y. Charde, "Simultaneous estimation of levodopa and carbidopa by RP-HPLC using a fluorescence detector: its application to a pharmaceutical dosage form," Luminescence, vol. 29, no. 7, pp. 762-771, 2014.

[24] R. P. Ribeiro, J. C. Gasparetto, R. De Oliveira Vilhena et al., "Simultaneous determination of levodopa, carbidopa, entacapone, tolcapone, 3-0-methyldopa and dopamine in human plasma bu an HPLC-MS/MS method," Bioanalysis, vol. 7, no. 2, pp. 207-220, 2015.

[25] R. D. O. Vilhena, F. L. D. Pontes, B. M. Marson et al., "A new HILIC-MS/MS method for the simultaneous analysis of carbidopa, levodopa and its metabolites in human plasma," Journal of Chromatography B, vol. 967, pp. 41-49, 2014.

[26] G. Wu, "The determination of levodopa in plasma by HPLC: a cautionary note," Chromatographia, vol. 52, no. 5-6, pp. 371-372, 2000.

[27] X.-Y. Zhang, W. Zhou, J. Yang, and G.-L. Duan, "Pharmacokinetic study on levodopa and benserazide hydrochloride tablets in beagle dogs by HPLC-ESI-MS/MS," Latin American Journal of Pharmacy, vol. 31, no. 9, pp. 1238-1246, 2012.

[28] I. d. César, R. M. Byrro, F. F. D. E. S. Cardoso et al., "Simultaneous quantitation of levodopa and 3-O-methyldopa in human plasma by HPLC-ESI-MS/MS: application for a pharmacokinetic study with a levodopa/benserazide formulation," Journal of Pharmaceutical and Biomedical Analysis, vol. 56, no. 5, pp. 1094-1100, 2011. 
[29] W. Jiang, L. Lv, S. Zhou et al., "Simultaneous determination of L-dopa and its prodrug (S)-4-(2-acetamido-3-ethoxy-3oxopropyl)-1,2-phenylene diacetate in rat plasma by high performance liquid chromatography-tandem mass spectrometry and its application in a pharmacokinetic study," Journal of Pharmaceutical and Biomedical Analysis, vol. 53, no. 3, pp. 751754,2010

[30] C. Muzzi, E. Bertocci, L. Terzuoli et al., "Simultaneous determination of serum concentration of levodopa, dopamine, 3-Omethyldopa and alpha-methyldopa by HPLC," Biomedicine \& Pharmacotherapy, vol. 62, no. 4, pp. 253-258, 2008.

[31] S. Mennickent, M. Nall, M. Vega, and M. de Diego, "Quantitative determination of L-DOPA in tablets by high performance thin layer chromatography," Journal of Separation Science, vol. 30, no. 12, pp. 1893-1898, 2007.

[32] J. Wang and Y. Fang, "Determination, purity assessment and chiral separation of levodopa methyl ester in bulk and formulation pharmaceuticals," Biomedical Chromatography, vol. 20, no. 9, pp. 904-910, 2006.

[33] G. Cannazza, A. Di Stefano, B. Mosciatti et al., "Detection of levodopa, dopamine and its metabolites in rat striatum dialysates follwing peripheral administration of L-DOPA prodrugs by mean of HPLC-EC," Journal of Pharmaceutical and Biomedical Analysis, vol. 36, no. 5, pp. 1079-1084, 2005.

[34] M. Z. Ahmad, K. A. Hamid, and T. J. B. Effendi, "A validated high-performance liquid chromatgraphic method for the determination of levodopa in rat plasma \& its application in pharmacokinetic studies," IEEE Symposium on Business, Engineering and Industrial Applications, pp. 134-139, 2012.

[35] H. F. Martins, D. P. Pinto, V. d. Nascimento, M. A. Marques, and F. C. Amendoeira, "Determination of levodopa in human plasma by high performance liquid chromatography-tandem mass spectrometry (HPLC-MS/MS): application to a bioequivalence study," Química Nova, vol. 36, no. 1, pp. 171-176, 2013.

[36] E. Wollmer and S. Klein, "Development and validation of a robust and efficient HPLC method for the simultaneous quantificiation of levodopa, carbidopa, benserazide and entacapone in complex matrices," Journal of Pharmaceutical and Biomedical Analysis, vol. 20, pp. 258-269, 2017.

[37] P. Bhatnagar, D. Vyas, S. Sinka, and A. Gajbhiye, "HPLC method for estimation of drug release of entacapone in entacapone, levodopa and carbidopa tablets," International Journal of Pharmaceutical Sciences and Research, vol. 8, no. 4, pp. 1734-1743, 2017.

[38] P. Bhatnagar, D. Vyas, S. Sinka, and A. Gajbhiye, "HPLC method for estimation of drug release of levodopa and carbidopa in entacapone, levodopa and carbidopa tablets," International Journal of Pharmaceutical Sciences and Research, vol. 8, no. 3, pp. 1091-1101, 2017.

[39] A. Soumyanath, T. Denne, A. Hiller, S. Ramachandran, and L. Shinto, "Analysis of levodopa content in commercial mucuna pruriens products using high-performance liquid chromatography with fluorescence detection," The Journal of Alternative and Complementary Medicine, vol. 24, no. 2, pp. 182-186, 2018.

[40] S. Kakarla, G. Kodali, and G. Seru, "Selective and rapid LCMS/MS method for the simultaneous quantitation of levodopa and carbidopa in human plasma using alümina spe cartridges," Indo American Journal of Pharmaceutical Sciences, vol. 3, no. 8, pp. 905-915, 2016.

[41] P. P. Raot and S. Y. Charde, "Simultaneus estimation of levodopa, carbidopa and 3-oxymethyldopa in rat plasma using
HPLC-ECD," Biomedical Chromatography, vol. 30, no. 10, pp. 1696-1700, 2016.

[42] I. C. César, R. M. Byrro, F. F. Santana e Silva Cardoso et al., "Development and validation of a high-performance liquid chromatography-electrospray ionization-MS/MS method for the simultaneous quantitation of levodopa and carbidopa in human plasma," Journal of Mass Spectrometry, vol. 46, no. 9, pp. 943-948, 2011.

[43] Y. M. Issa, M. E. M. Hassoun, A. G. Zayed, and G. Ashrat, "Application of high performance liquid chromatographic method for the determination of levodopa, carbidopa and entacapone in tablet dosage forms," Journal of Liquid Chromatography \& Related Technologies, vol. 34, no. 19, pp. 2433-2447, 2011.

[44] F. Bugamelli, C. Marcheselli, E. Barba, and M. A. Raggi, "Determination of L-dopa, carbidopa, 3-O-methyldopa and enracapone in human plasma by HPLC-ED," Journal of Pharmaceutical and Biomedical Analysis, vol. 54, no. 3, pp. 562-567, 2011.

[45] S. F. Li, H. L. Wu, Y. J. Yu et al., "Quantitative analysis of levodopa, carbidopa and methydopa in human plasma samples using HPLC-DAD combined with second-order calibration based on alternating trilinear decomposition algortihm," Talanta, vol. 81, no. 3, pp. 805-812, 2010.

[46] N. G. Mohamed, G. Nashwah, and M. S. Mohamed, "Determination of antiparkinsonism drug entacapone," Journal of Alternative and Complementary Medicine, vol. 55, no. 1, pp. 8589, 2010.

[47] M. Karimi, J. L. Carl, S. Loftin, and J. S. Perlmutter, "Modified high-performance liquid chromatography with electrochemical detection method for palsma maesurement of levodopa, 3O-methldopa, dopamine, carbidopa and 3,4-dihydroxyphenyl acetic acid," Journal of Chromatography B-Analytical Technologies in The Biomedical and Life Sciences, vol. 836, no. 1-2, pp. 120 123, 2006.

[48] K. A. Sagar and M. R. Smyth, "Simultaneous determination of levodopa, carbidopa and their metabolites in human plasma and urine samples using LC-EC," Journal of Pharmaceutical and Biomedical Analysis, vol. 22, no. 3, pp. 613-624, 2000.

[49] V. Junnotula and H. Licea-Perez, "Development and validation of a simle and sensitive method for quantification of levodopa and carbidopa in rat and monkey plasma using derivatization and UPLC-MS/MS," Journal of Chromatography B-Analytical Technologies in The Biomedical and Life Sciences, vol. 926, pp. 47-53, 2013.

[50] J. Chi, Y. H. Ling, R. Jenkins, and F. M. Li, "Quantitation of levodopa and carbidopa in rat plasma by LC-MS/MS: the key role of ion-pairing reversed-phase chromatography," Journal of Chromatography B-Analytical Technologies in The Biomedical and Life Sciences, vol. 1054, pp. 1-9, 2017.

[51] C.-L. Mu, D. Wu, H.-F. Lu, H. Xie, and Q.-L. Zhang, "Simultaneous and sensitive determination of levodopa and carbidopa in pharmaceutical formulation and human serum by hidg performance liquid chromatography with on-line gold nanoparticlescatalyzed luminol chemiluminescence detection," Chinese Journal of Analytical Chemistry, vol. 45, no. 6, pp. e1726-e1733, 2017.

[52] K. V. Özdokur, E. Engin, Ç. Yengin, H. Ertaş, and F. N. Ertaş, "Development of carbidopa, levodopa and droxidopa by highperformance liquid chromatography-tandem mass spectrometry," Analytical Letters, vol. 51, no. 1-2, pp. 73-82, 2018.

[53] M. Khanmohammadi, E. Mobedi, A. B. Garmarudi, H. Mobedi, and K. Kargosha, "Simultaneous determination of levodopa and carbidopa in levodopa-carbidopa tablets by ATR-FTIR 
spectrometry," Pharmaceutical Development and Technology, vol. 12, no. 6, pp. 573-580, 2008.

[54] Z. Talebpour, S. Haghgoo, and M. Shamsipur, "H-1 nuclear magnetic resonance spectroscopy analysis for simultaneous determination of levodopa, carbidopa and methyldopa in human and pharmaceutical formulations," Analytica Chimica Acta, vol. 506, no. 1, pp. 97-104, 2004.

[55] S. Fanali, V. Pucci, C. Sabbioni, and M. A. Raggi, "Quality control of benserazide-levodopa and carbidopa-levodopa tablets by capillary zone electrophoresis," Electrophoresis, vol. 21, no. 12, pp. 2432-2437, 2000.

[56] P. T. Ha, A. Van Schepdael, T. Hauta-aho, E. Roets, and J. Hoogmartens, "Simultaneous determination of dopa and carbidopa enantiomers by capillary zone electrophoresis," Electrophoresis, vol. 23, no. 19, pp. 3404-3409, 2002.

[57] P. G. Ertokuş, Z. Mermertas, and A. M. Akkaya, "Application of chemometric methods to quantative analysis of drugs used in parkinson's disease," SF Journal Of Pharmaceutical and Analytical Chemistry, vol. 1, no. 2, pp. 1-8, 2018.

[58] D. Sharma, R. Singh, and R. Garg, "Development and validation of stability indicating UV spectro-photometric method for the estimation of benzydamine hydrochloride in bulk and in pharmaceutical dosage form: a novel analytical technique for conducting in-vitro quality control tests," International Journal Of Pharmaceutical Sciences And Research, vol. 9, no. 2, pp. 678686, 2017.

[59] J. Miao, B. Forget, and K. Smith, "Predicting correlation coefficients for Monte Carlo eigenvalue simulations with multitype branching process," Annals of Nuclear Energy, vol. 112, pp. 307321, 2018.

[60] N. Abbai and S. A. Parameswari, "Stability indicating RPHPLC method development and validation for simultaneous estimation od salbutamol and beclomethasone in bulk and tablet dosage form," International Journal of Pharmaceutical Sciences and Research, vol. 9, no. 5, pp. 1980-1988, 2018.

[61] P. Deshpande and V. Mandawad, "Development and validation of stability indicating HPTLC method for determination of azelastine hydrochloride as bulk drug and in pharmaceutical liquid dosage form," Indo American Journal of Pharmaceutical Sciences, vol. 5, no. 6, pp. 5107-5113, 2018.

[62] D. Aravind and S. K. Kamarapu, "Method development and validation of RP-HPLC method for simultaneous estimation of clidinium bromide chlordiazepoxide and dicylomine hydrochloride in bulk and combined tablet dosage forms," International Journal of Pharmacy \& Bio-Sciences, vol. 3, no. 3, pp. 152-161, 2013.

[63] A. Uyanık, "Analitik Kimyacılar İçin İstatistik ve Kemometri," in Pegem Akademi Yayıncılı, vol. 6, pp. 254-259, Baskı, Türkiye, 2012.

[64] A. V. Bilgili, M. A. Çullu, and S. Aydemir, “Tuzdan etkilenmis topraklarin yakin kizilötesi yansima spektroradyometre ve elektromanyetik indüksiyon teknigi yardimiyla karakterize edilebilme potansiyelinin arastirilmasi," Harran Tarim ve Gida Bilimleri Dergisi, vol. 18, no. 1, pp. 32-45, 2014.

[65] A. Shrivastava and V. B. Gupta, "Methods for the determination of limit of detection and limit of quantitation of the analytical methods," Chronicles of Young Scientists, vol. 2, no. 1, pp. 21-25, 2011.

[66] D. A. Armbruster and T. Pty, "Limit of blank, limit of detection and limit of quantitation," The Clinical Biochemist Reviews, vol. 29, pp. 49-52, 2008.
[67] V. Bajpai, S. Kumar, A. Singh et al., "Chemometric based identification and validation of specific chemical markers for goegraphical, seasonal and gender variations in tinospora cordifolia stem using HPLC-ESI-QTOF-MS analysis," Photochemical Analysis, vol. 28, no. 4, pp. 277-288, 2017. 

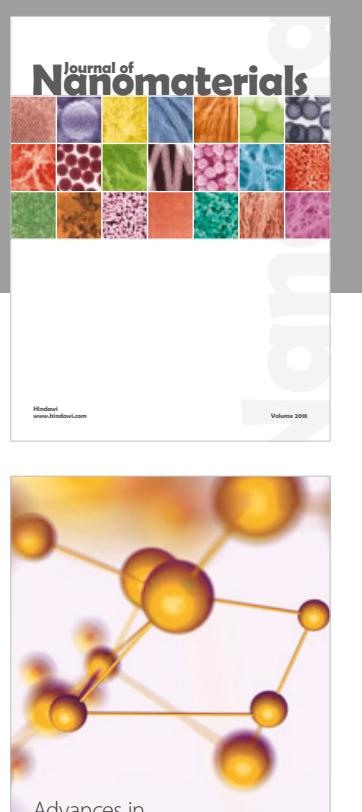

Physical Chemistry
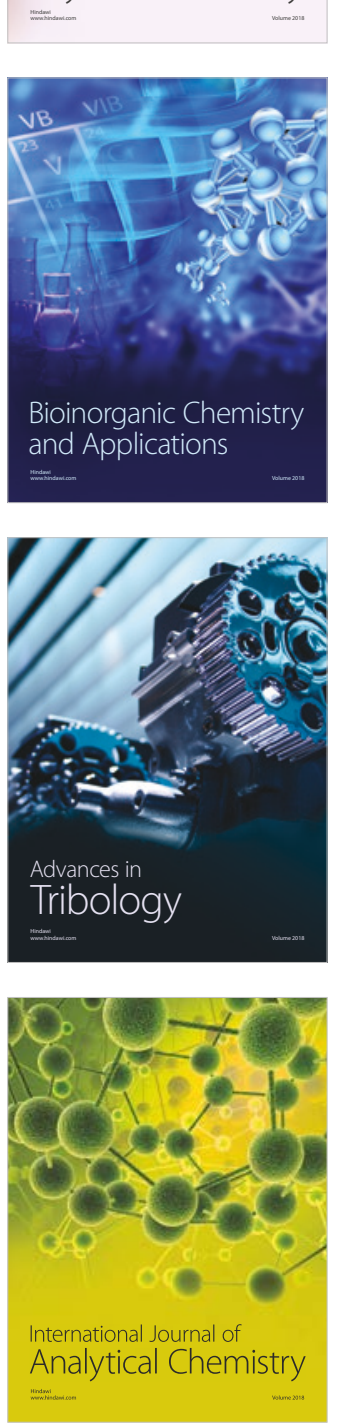

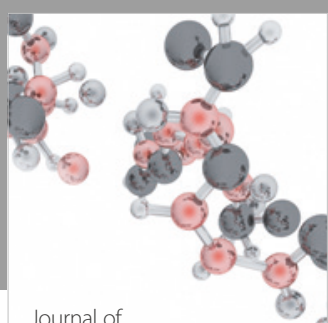

Analytical Methods

in Chemistry

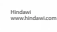

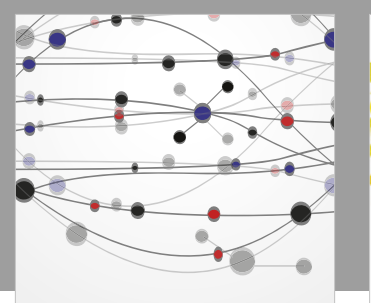

The Scientific World Journal

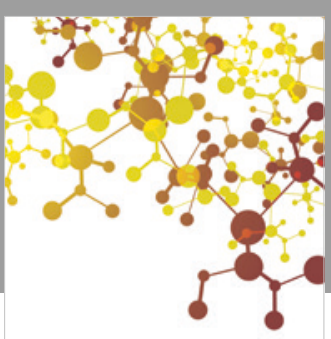

Journal of

Applied Chemistry
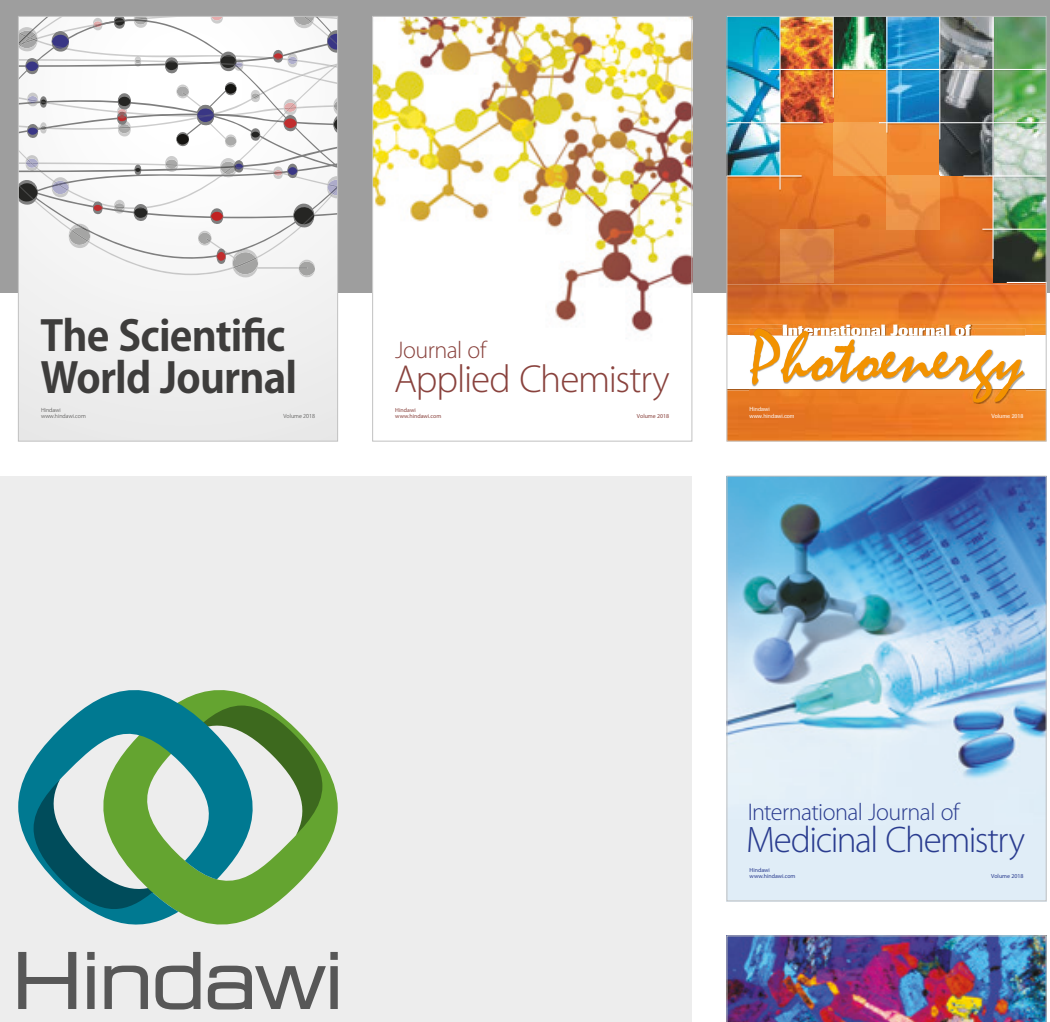

Submit your manuscripts at

www.hindawi.com
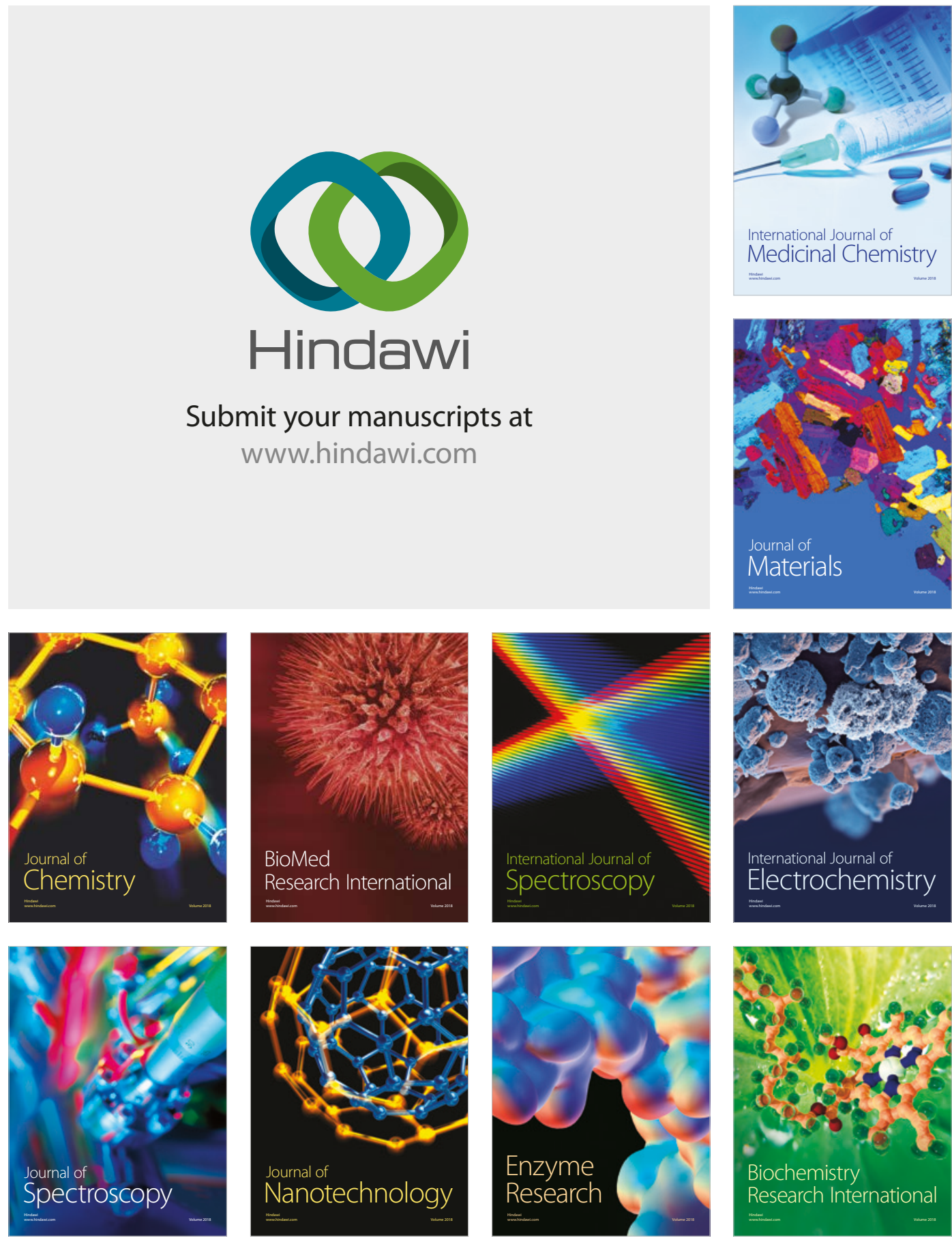
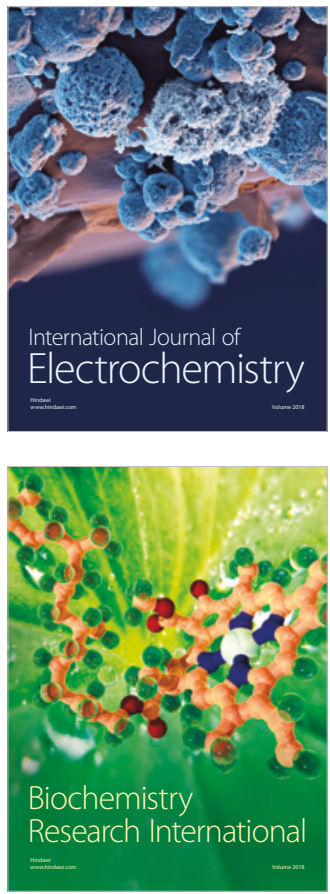